\title{
THE IMPLEMENTATION OF TEACHING ENGLISH SECONDARY LEVEL IN PRIVATE SCHOOLS AND THE STUDENTS RESULT
}

\author{
Khudriyah \\ STIT al Urwatul Wutsqo Jombang \\ E-mail: azkiabilqis@gmail.com
}

\begin{abstract}
The objective of teaching English as foreign language in Indonesia is the students are competence in oral and written language. This study is aimed to know wether or not the objective of the government policy has been reached. The design of the research is qualitative descriptive. the data collection technique used observation, questionnaire interview and documentation. The result of the study showed that the students result of learning English in private schools is very low in which the students did not understand spoken or written text. They even could not practice English orally or in writing. In implementing teaching English, the teachers did not conduct the objective of teaching English has been stated by Indonesia government. Besides, the teaching and learning process, they have conducted, did not apply the teaching language principles. In this case Indonesia government has to review the teaching and learning process especially in private schools, and the teachers have to consider and learn how to teach the language and language skills.
\end{abstract}

\section{Keywords: Implementation, Teaching English, Private Schools, Result}

\begin{abstract}
Abstrak
Tujuan pembelajaran bahasa Inggris sebagai bahasa asing di Indonesia adalah siswa memiliki kompetensi untuk berkomunikasi baik secara lisan maupun tertulis. Penelitian ini bertujuan untuk mengetahui apakah tujuan pembelajaran bahasa Inggris di sekolah swasta yang sudah ditetapkan pemerintah sudah tercapai atau belum. Penelitian ini menggunakan pendekatan kualitatif deskriptif. teknik pengumpulan datanya menggunakan observasi, interview, dan dokumentasi. Hasil penelitian menunjukkan bahwa: hasil belajar bahasa Inggris siswa di sekolah swasta sangat rendah, yaitu siswa tidak memahami bahasa Inggris baik secara lisan maupun secara tertulis, bahkan siswa tidak mampu berbicara maupun menulis bahasa Inggris; Para guru ketika mengajar bahasa Inggris di dalam kelas, tidak melaksanakan pembelajaran bahasa sesuai dengan tujuan pembelajaran yang sudah ditetapkan oleh pemerintah; Proses pembelajaran bahasa Inggris di kelas tidak sesuai dengan prinsip pembelajaran bahasa Inggris. Berdasarkan temuan tersebut, maka pemerintah harus mereview proses pembelajaran bahasa Inggris terutama di sekolah swasta, dan guru harus mempertimbangkan dan belajar lagi mengenai bagaimana cara mengajar bahasa dan ketrampilan berbahasa Inggris.
\end{abstract}

Kata Kunci: Penerapan, Mengajar Bahasa Inggris, Sekolah Swasta, Hasil Belajar 


\section{A. Introduction}

English as international language has spread to all parts of the world and has been spoken in many countries both as native, second or foreign language. It is rightly as the lingua franca, the language that is widely used as means of communication among speakers of different native languages. English can be said as science and technology language, since no other language has offered such a wide scope for scientific studies and research as English. Besides, English is also used as all knowledge in most the word. It means that English very important to be mastered.

The Indonesia government policy of teaching English was stated at depdiknas 2004. The objective of English learning is the students are competence in oral and written language. The competence standard also explains that the students communicate orally and in writing. The objective of the English learning involves four skills, they are listening, speaking, reading, and writing (Depdiknas, 2004). This is the form of government about globalization era in which the triumph is determined by the quality of human resources. Meanwhile the quality of human resources is determined by educational quality. English is as one of the terms which support educational caliber since many good and important sources is written in English.

As a developing country, Indonesia has implemented English as foreign language. So English is only implemented in the school periode with limited time in which the students will use English only in the classroom, when they are out of class they will leave English. Meanwhile English is not knowledge. It is skill. The learners must have the knowledge of that language, and practice it as well as possible.

Discussing about basic principle of language learning is learning a language is having skill of the language as explained by Bouchard (1980:213) that "language learning is essentially a process of habit information. It is a skill which develops by persistent practice". Practice actively leads to perfection and infact, it is needed in all the fundamental skills in language learning, in understanding oral and written English, and in speaking and writing English. 
Learning foreign language needs hard working since it is complex process. As Graft (1985:60) says that "learning foreign language needs to involve a new culture, new way of thinking, feeling and acting. The learners have to be fluent, accurate and meaningfull" It shows that learning English as foreign language is not only learn the language but also many things about the language. Succsessful language learning involves an interrelationship of cognitive, affective, and psycal processes. Learners use different style and strategies depending on these factors to learn language (Strong, 1991:234). That is why, it is alright that practice in spoken and written the language must be done in the teaching and learning process.

Language learning is not learning about the language, but it is an activity to foster students to use language as a communication tool as speakers. It means the students are trained in language skills which only mastered through practice speaking. So, learning a language is an activity to use language as a communication tool that should be done through the practice of using language, and it is not the activity of studying the theory or knowledge of the language, and the learning process in the classroom should make the language as a means of communication. There is no difference curriculum in teaching English in state and private secondary level in Indonesia notwithstanding, different output even differ greatly. Such difference make students and parents would prefer a state school. This is a big problem that must be overcome.

According to Ghozali (2011) "the attention of the students' development and progress of achievements in private schools more prominent. This is because generally, the number of students in state schools is different greatly than in private schools. So that it is impossible when the state schools should monitor all their learners with the utmost attention". This statement is not evident in the rural area. The result of the English competence is different between state and private schools. That is why the researcher wants to know the reasons.

Many research result showed that such problem can be from method used by teachers, students, and teachers themselves, etc. And this study will examine the probelm that comes from teachers and the teaching and learning problem. Teaching is a process guiding, assisting and facilitating the learners. Teachers understand how the learners learn, determine the teaching style, approach, 
methods, classroom technique, and phylosophy of education. The statement means that teachers in the teaching and learning process have to prepare everything relates to their teaching such as understand their students needs, use appropriate methods, strategy, technique, and so forth.

Brown (2001:2) says that "people who have decided to be a language teacher, they will have profession that guarantee them more than their fair share of challenges, growth, and fulfillment". It means that teaching a language foreign or second language will find a lot of challenges that must be solved to attain the teaching objective. Based on the above contention, the teachers task before teaching has to be prepared as well as possible and must be appropriate with students' need. This case what is called teaching device. By preparing students' need in the class, the process of teaching learning language can be achieved and students achievement will increse well. As Arikunto (2006) says to produce a good learning process, the process of interaction between teachers and students as well as other learning resources should be good and conducive. This resulted in increasing their achievement. It can be concluded that there is correlation between teaching technique with students' achievement. In reality, anyway, many teachers even English teachers prefer to copy it which belonging to other schools. It proves that their seriousness in fulfilling their profession as a teacher is very weak. Such conditions, if done continuously will lead to decreasing the quality of education that will harm the country.

Indonesia government has stated learning English as foreign language in four language skills, such as listening, speaking, reading and writing that should be implemented in the classroom teaching and learning process. (Brown, 2001: 7) states that "Teaching is showing or helping to learn how to do something, giving instruction, guiding the study of something, providing with knowledge, causing to know or understand. It means that teaching is enabling learners to know and understand how to do something they want to expect by giving them instruction, guiding, and providing knowledge. And related to language learning, the teachers also have to provide the learners how to use the language, because language is not only knowledge but also skill. 
Learning and teaching foreign languge is difficult and boring work, however, the teachers and the learners must have high motivation and high desire to master the language. Even the teacher must be able to make the students are interested in the learning. It also describes that the key of of sucsessful in the teaching and learning process is hanging on the teachers. The teachers have to be capable in constructing the learners' motivation, interest, and conducive classroom environment. There are many ways to increase students motivation, and one which comes from teacher is constructing students motivation, that is the teachers have to engage themselves to help students achieve their results. It means the teachers leads students to improve their skills in teaching and learning, and helps them in achieving personal goals and evaluate their progress. This is rarely done by most teachers.

The method of teaching English must be elastic and adoptable (changable) as life is restless and variable (Palmer, 1987:65). Using monotonuous method thing can cause boredom and decrease motivation. Students who are bored tend to disrupt the learning process. Elastic and changable method will keep students engaged and motivated. Such method are making the division of roles, the debate, the transfer of knowledge briefly, discussions, simulations, case studies, audiovisual presentations and small group work. In designing learning environments the behaviorist or empiricist view emphasizes routines of activity for effective transmission of knowledge. The learning program has to be well organized with routines for classroom activity that students know and follow easily (Greeno et al. 1996). This is the teachers' task to be a qualified teacher, they should make the class interesting, the teachers must love their profession as teacher, their personality must be constructed well, the teachers have to study more to have broader knowledge, and a teacher is an entertainer in a positive sense (Harmer, 2004:1-2).

\section{B. Literature Review}

Brown (2001:258-259) in his book of teaching by principle explain about principle of four skills of English (listening, speaking, reading, and writing) and the principle of teaching listening are: Focus on Listening in an integrared skills 
course; Use technique that are intrinsically motivated; Utilize authentic language and contexts; Carefully consider the form of listener's responses; Encourage the development of listening strategies; Include both bottom up and top down techniques.

The following is such principles of teaching speaking as: Focus on both fluency and accuracy depend on the objective; Provide intrinsically motivating techniques; Encourage the use of authentic language in meaningful contexts; Provide appropriate feedback and correction; Capitalize on the natural link between speaking and listening; Give students opportunity to intiate oral communication; Encourage the development of speaking strategies. (Brown, 2001: 275-276)

The next is productive skills (reading and writing), as he says about teaching reading principles are: Focus on reading skills; Provide intrinsically motivating techniques; Balence authenticity and readability in choosing text; Encaurage the development of reading strategies; Include both bottom up and top down techniques; Follow the "SQ3R" sequence (survey, question, read, recite, review); Devide technique into pre reading, during reading and after reading; Infer comprehension in other behaviour (Brown, 2001: 313-315).

The last is the principle of teaching writing as follows:Incorporate practice of good writers; Balence process and product; Account for cultural/literary backgrounds; Connect reading and writing; Provide as much authentic writing as possible; Frame the technique in to pre writing, drafting and revising. (Brown, 2001:346-347). The teachers who implement the above principles well, will be success in their learning process. However, There are many criticisms about the faulty of teaching English in Indonesia in general. One of them is the curriculum. However the researcher is sure that there is another reason of the failure of the teaching English that will be investigated in this research. The result of non formal interview and observation showed that some English teachers still use monotonous strategy. They liked to teach grammar, and the result of students achevement was categorized very low. 


\section{Method}

This study is a qualitative research, which is a method that is use the thinking process, begins with collecting data, then the data from the study is concluded in general. The informants are the English teachers and students of private school. Data were collected through interviews and observations. Furthermore, the data were processed using descriptive analysis results interviews and observations through data collection; data reduction with the manufacture of coding and category; presentation of data; as well as the conclusion.

In this case, the researcher used purposive sampling technique. According to Djarwanto (1998) "Purposive sampling is a sampling method which carefully selected to make the research structures is relevant, in which the sample are chosen appropriate with specific characteristics" And because of limitations of time and costs, the informants were chosen were the English teachers and students of private Madrasah Aliyah and Tsanawiyah. In analyzing data, the researcher explained and gave a description of the results of interviews and observations between English teachers and students, then the data on test validity using triangulation of methods and subject.

\section{Result}

Discussing students' result in this research is the result of four skills of English, they are listening, speaking, reading, and writing. The average result of students achievement of lerning English in private school is very low. As many students said that they did not understand English very much. When they were asked about listening they said that they got difficulties in understanding the spoken text, or they did not understand what the speakers said. Related to speaking, the students said that they couldn't speak English well. They also said they were lazy to read English text since they did not know the meaning. Even when they were asked about writing, most of them said that they couldn't write English because they were never taught writing. Like Vk said, “ saya nulis judulnya aja gak bisa apa lagi nulis Inggris".

The researcher then met some students who categorized as a proficient student in English, such as Rc, she said" well I got English since taking course". 
The next was student with initials P, said " I hated English so much, but after my sister asked me to joint course, ehm I like English very much". Iv said, "after taking course my roommate had not insulted me anymore, it is because of my English". The above phenomenan shows that the students result of learning English in the classroom in private school is low, except those who have taken a course out of classroom.

The result of interview from the English teachers showed that some of them taught speaking, reading and little listening, and most of them didn't teach writing. The following are their responses about how they taught English in the classroom. The students with initials L, said, she taught four skills, listening by giving the students some song, then students fill blank space. When the students in the third grade of SMA they were taught listening by listening of national examanation before. In teaching speaking she asked her students to make conversation about the material given, then for the following meeting they practice it. She then explained that she corrected the grammar when the students made mistake. In teaching reading, she gave the students some texts then students anwered the questions related to the text. While in teaching writing, she asked her students to write in their home as home work. The students were asked to write a text like the text given, then it was submitted on the following meeting, then she gave score. Like wise L, one of English teacher in another school.

Different from another teacher with initials $U$, she just taught grammar and some times she taught listening by giving a song, then the students filled the blank space prepared. Meanwhile Ainun in her explanation, she taught English only focus on reading because she prepared her students on national examination. In another place Sf (teacher) explains about how he taught English to the classroom. He said that he taught English only focus on grammar. The finding also supported by $\mathrm{R}$, one of senior high students, she described how her teacher conducted the teaching and learning process. She said that in reading comprehension, her teacher taught her class by giving some questions to be answered. It was used to lead students to the material, after that the teacher explained about the material, the students then were asked to analyse the generic structure of the text and answered the questions related to. In speaking class, she always gives the students 
homework related to the material to be spoken for the next meeting. Richa then said that her teacher never gave listening or writing.

In line with R, Ns expalined that her teacher liked to teach LKS, some times she taught grammar. The next information was from the first grade student of junior high school with initials $\mathrm{Y}$, also explained that his teacher always taught grammar and vocabulary. However, all students like the style of his teaching. He then answered, his teacher never taught reading or writing, but it will be taught at second and third class. His explanation was supported by one of the third grade students that reading is taught at second and third class, and it is focused to national examination.

Another student said that the implementation of English learning in his class was: in teaching listening, the students were asked to listen carefully. He then read the text, after that he questioned the content of the text which was read by teacher. In teaching reading, his teacher explained genre of text on the text book, then he asked students to understand the content of the text, after that the students answered the questions. The last was the answer was discussed together. The teacher never practiced speaking and writing. Asking about the students response. He said that some times the class felt bored because his pronunciation unliked native speakers. As he said "anak anak bosenya karena mbacanya gak kayak aslinya yang di film atau lagu".

The result of observation, the researcher proved that most English teachers taught English with monotonuos method, and clasically. The researcher never found the teachers taught by making group or discussion. As what was done by Dian, she just asked her students to open their LKS, then asked them to answer the questions under the text, then some students asked the meaning of vocabulary. Sometime she asked them to open their own dictionary.

In a seperate place, the researcher met a teacher who taught her students by writing some of grammar on the white board, then she expalined and asked them to question if they did not understand, after that she gave a test. When the researcher asked about how to teach writing, she said that she never teach writing, because her students were more intersted in grammar, she said that her students 
often complained when they were taught writing, moreover, she said that writing is not included in national examination.

The researcher then asked her about the method in teaching writing, she said that she asked them to write one of genre based on topic given, or some times the students might choose another topic freely. After that their written text is submitted, and the result is not good. When the researcher went in to a school office, she found one of English teachers of that school, she asked to her student, "hi mbak please take my tissue yes, on the table, I forget te. After asking many question about her, then researcher asked about how to teach English in the class. She said that she taught speaking by question aswer strategy in which before speaking class, she assigned students to prepare a text for example about daily activity, or hobby, then the text was given to the teacher, and the teacher would ask about the text. Answering the question about how to correct the students error of pronunciation, she said that she hardly ever corrected their pronunciation, usually she corrected grammar and the wrong answer. In teaching reading she said that she gave them a text, and the students answered the questions and she gave score. Finally she said that she never teach listening and writing.

\section{E. Discussion}

The teaching and learning process in some private schools didn't apply four skills. Some of them only teach listening and reading, some of them only implemented teaching of grammar. And almost the teachers did not include the teaching of writing in the teaching and learning process. This matter does not follow the rules outlined in the regulations depdiknas (2004) "English is taught as a foreign language in Indonesia and its aim is to enable students to master the four English skills, i.e. listening, speaking, reading, and writing.

Based on the principles of teaching language according to Brown is in the teaching of listening, the teachers must focus on listening in an integrared skills course. Intergrated skill is students are to work on all four language skills in the class: listening, speaking, reading, and writing. Song can be integrated skills when the teachers implement songs with technique that is able to encompass the four skills, however, the teachers in private schools implemented song as strategy 
didn't encompass the four skills. They only asked the students to listen to music then they filled the blank space. Song can be a technique that instrinsically motivated, because most people like to listen music even students. That's why song that implemented has motivated students instrinsically.

The song which has been used as technique of teaching listening utilized authentic language and contexts, because the teacher applied western song with originil singer. However, the teacher didn't carefully consider the form of listener's responses. In this case there was no feed back after teaching listening. The teacher asked the students to exchange answer sheets to their friends, and then discussed the results of correct answer, and the students collected the answer sheets to be distributed at the next meeting, the teacher then left the class.

The teaching of listening in private school didn't encourage the development of listening strategies, because the teacher just asked the students to listen a song carefully then they had to fill blank space. Meanwhile listening stragies is a technique or activity that directly improve the understanding and remembrance of someone on the listening input. Listening strategies are classified according to the way a listener to process the input. In real life listening, people used to use certain strategies which depend on the reason or cause them to do the listening. The teaching of listening in private school only used buttom - up strategy because the teacher did not ask students to know the content of the song. The students were only careful to listen the song lyric to avoid mistake in filling the blank space.

The way of teaching listening implemented by other teacher in which the teacher read the English text and students listened and the students anwer questions related to text. This why did not reflect what Brown promoted most. It can achieve buttom-up only. However, it is not effective because the teacher had many mistake especially in pronouncing words. The teaching of speaking in private school did not Focus on both fluency and accuracy. The teacher only reminded the students mistake on grammar, even the teachers did not remind them in pronunciation. They just taught with purpose the students can speak fast. This violates the rules in learning, the strategy did not also provides intrinsically motivating techniques, because the students will be boring. The learning did not 
encourage the use of authentic language in meaningful contexts. The teacher didn't provide appropriate feedback and correction. They corrected only on their error grammar. The speaking process did not capitalize the natural link between speaking and listening. The learning process gave students opportunity to intiate oral communication. However, they were not guided. And the teaching of speaking did not encourage the development of speaking strategies.

The teaching of reading in private school was the teacher gave a text, the students read the text and answering questions, the teacher explained the generic structure and feature of the text, then the students read the text $\mathrm{s}$ and answered the questions. Sometimes the students tried to analyse the generic structure. This why doesn't reflect the teaching of reading promoted by Brown.

This why did not focus on four skills, only for understanding the reading content or the component or structure of the text when the students learn to write. LKS text is not authenticity and readability, because most LKS are written by Indonesia teacher, and mostly the texts are translated from Indonesia in to English. Reading strategy should be getting ready to read, in which the students have to analyze feature, finding organizational pattern, anticipational guide, signal words and vocabulary meaning; enagging to reading, reacting to reading, reading different text form. Meanwhile the teacher in teaching reading only in the part of getting ready to read. The teacher in teaching reading also did not include both bottom up and top down techniques, and did not follow all of SQ3R" sequence. (survey, question, read, recite, review). If so in part of questions. This way also did not apply reading skills.

There are principles in teaching writing, the teacher must teach: how to write well or how to be good writer; balance process and product; Account for cultural/literary backgrounds; connect reading and writing; provide as much authentic writing as possible, and frame the technique in to pre writing, drafting and revising. However, The teacher of private school did not teach like what principles above, they taught their students only product writing. They just asked them to write like the example they had set, while a product will not be qualified without going through a long process. 
Based on the above finding, means that teaching English in private schools does not refer to the principles stated by Brown and does not follow the rules has set by the government. In which "the objective of the English learning involves four skills in learning language, they are listening, speaking, reading, and writing".

\section{F. Conclusion}

The students result of English in private school was very low, because most of them could not use English as expected by government. They did not understand spoken or written text. They even could not practice English orally or in writing. In implementing of teaching English, the teachers did not conduct the objective of teaching English has been stated by Indonesia government. Some of them only taught three skills (listening, speaking, and reading). Some of them taught two skills, that is listening and speaking. Few of them taught writing, and most of them taught grammar. However, in the teaching and learning process, they did not apply the teaching language principles has been promoted by Brown overall. Based on the finding, the researcher suggested Indonesia government to review the teaching and learning process especially in private schools, and for teachers to consider and learn how to teach the language and language skills as promoted by Brown.

\section{References}

Arikunto, Suharsimi. 2006. Prosedur Penelitian (Suatu Pendekatan Praktik). Edisi Revisi, Jakarta : Rineka Cipta

Bouchard. D.L. 1980. Principle of Language Learning and Teaching. New Jersey. Prentice Hall . Inc. USA.

Brown. H.D. 2001. Teaching by Principle. An Interactive Approach to language pedagogy. $2^{\text {nd }}$ ed. New York : Addision Wesley Longman.

Depdiknas. 2004. Kurikulum Berbasis Kompetensi (Competence Based Curriculum). Jakarta: Depdiknas.

Depdiknas. 2006. Peraturan Menteri Pendidikan Nasional Repuplik Indonesia Nomor 22 Tahun 2006. (Ministery Decrees of National Education No 22 Year 2006). Jakarta: Direktorat Pendidikan Dasar dan Menengah.

Djarwanto, Ps dan Pangestu Subagyo. 1998. Statistik Induktif. Yogyakarta : BPFE Yogyakarta. 
Gozali Imron. 2011. Belajar dimana ya? Sekolah Negeri atau swasta. http://ceritabersama-tati.blogspot.com/2012/01/perbedaan-sekolah-negeridan-swasta.html (20/05/2015)

Graff. W. 1985. Language and Learning Principle. Long mans Green and Co. Ltd London UK.

Greeno, J.G., Collins, A.M., \& Resnick, L.B 1996. Cognition and Learning. In D.C. Berliner \& R.C. Calfee (Eds.), Handbook of educational psychology. New York: MacMillan.

Harmer, J. 2004. How to Teach English. New York: Longman.

Palmer. H. 1987. Quantity before Quality in Second Language Composition. In Raimes, A TEFL Anthology, ICA: Washington, UK.

Strong. H. 1991. Psycholinguistic and Language Teaching Methodhology and Bacan, Inc. Boston. 